\title{
Strategies for Enhancing the Productivity of Secondary School Teachers in South West Region of Cameroon
}

\author{
Sophie E. Etomes ${ }^{1,3}$ \& Ernest L. Molua ${ }^{2,3}$ \\ ${ }^{1}$ Department of Educational Foundations and Administration, University of Buea, SWR, Cameroon \\ ${ }^{2}$ Department of Agricultural Economics and Agribusiness, SWR, University of Buea, Cameroon \\ ${ }^{3}$ Centre for Independent Development Research (CIDR), Buea, Cameroon \\ Correspondence: Sophie E. Etomes, P.O. Box 58 Buea, SWR, Cameroon. E-mail: etomes2006@yahoo.com
}

Received: August 22, 2018

Accepted: October 2, $2018 \quad$ Online Published: December 30, 2018

doi:10.5539/jel.v8n1p109

URL: https://doi.org/10.5539/jel.v8n1p109

\begin{abstract}
This study investigates strategies used by principals for enhancing the productivity of secondary school teachers in selected government secondary schools in Cameroon. Four major strategies were examined. These include motivation, conflict resolution, supervisory and communication strategies and the extent to which they influence teachers' productivity. Four research questions and hypotheses guided the study. Questionnaire was used to collect data from 350 teachers selected from a population of 1400 teachers in government secondary schools in Fako Division of the South West Region of Cameroon. The multi-stage sampling technique was used to select teachers for the study. Results showed that, principals' communication, conflict management, supervisory and motivation strategies influence the productivity of teachers in Government Secondary Schools. Of the four strategies examined, conflict management strategy was found to have more influence on the productivity of teachers. Principals' strategies have a direct relationship with teachers' productivity. Therefore, there is a possible correlation between principals' leadership and management strategies, teachers' productivity and school effectiveness. In addition, effective collaboration amongst teachers is necessary for teachers' effectiveness. It is recommended that principals should put in strategies that will enhance effective communication, conflict management, motivation and supervision to improve on the productivity of teachers.
\end{abstract}

Keywords: Cameroon, secondary school, principal's strategies, teachers' productivity

\section{Introduction}

Secondary education occupies a central position in the education ladder. While it absorbs graduates from primary education, it prepares students for access into higher educational institutions. This gives secondary education its relevance. Low productivity in secondary education which is reflected in students' output, such as skills acquired, repetition, dropout amongst others have adverse effects on the society and students. For example, school dropout at this level limits future opportunities for students and also represents a significant drain of the limited resources that countries have for the provision of secondary education. UNESCO (1984) cited in Mutua (2014), reports that school dropouts are most likely candidates for unemployment and dropouts from secondary school are often the most disadvantaged in the job markets. Being educated, their educational aspirations are high. They are often not satisfied with traditional occupations or engaging in production at subsistence level. Moreover, family members expect them to engage in salaried work to bring returns to the investment that the family made. While successful leavers have difficulties in obtaining employment, these dropouts have an even more difficult task in securing jobs. It could be said that dropout is not only an economic and pedagogical issue, but also a social and political one (Mutua, 2014).

The efficient and effective management of any organization lies on the ability of the top management or its manager to motivate the workforce. In the case of secondary education in Cameroon and other parts of the world, the principal is the head of the school and the manner in which the principal performs his/her roles and functions are paramount in improving the teaching and learning environment for teachers to be productive. Principals are the main administrators of staff and students who are at the center of educational productivity; teachers are at the center of the teaching-learning process while students are the major stakeholders in education since their performance informs the educational community on how the school is faring. Therefore, if teachers are not 
productive, students will not be. Nwosu (2017), reports that teachers are arguably the most important group of professionals for our nation's future. Without teachers, the education system will be crippled. The increased importance in teacher's job performance has made it extremely important to identify the factors that influence teacher's job performance. Based on the above assertion, this study sets out to examine strategies that principals can use to improve on the productivity of teachers as a result of their position.

Principals, as the head of educational institutions are charged with the responsibility of implementing educational policies, teachers on the other hand are the principal actors for the achievement of the goals and objectives of education. Fagbamiye (2004), stated that the principal is essentially an organizer and implementer of plans, policies and programmes meant for specific educational objectives. His administrative tasks include directing the teachers and students in an environment conducive to the maximum development of the learners. Teachers play a pivotal role in the achievement of educational goals and objectives given that their effectiveness determines students output. This is also backed by Section 37(1) of Law No. 98/004 of $14^{\text {th }}$ April 1998 to lay down the guidelines of education in Cameroon which states that; "the teacher shall be the principal guarantor of quality education". Though there are other factors that contribute to teachers' productivity, principals as head of secondary schools has a paramount role to play in teachers' job performance.

Even though till present, educational administrators in Cameroon do not undergo any formal training, appointment into administrative positions is based on teaching experience and output, after obtaining formal training in the higher teachers training college. This indicates that they lack the conceptual skills in educational administration and management which creates a gap in effective management and administration of secondary schools. There are some questions that could be raised to begin addressing the challenges associated with teachers' productivity. Does the principal use of motivational strategies enhance teachers' productivity? Do supervisory strategies used by the principal enhance teachers' productivity? Do conflict management strategies of school affairs enhance teachers' productivity? Do communication strategies of the principal enhance teachers' productivity? The goal of this paper is thus to examine whether principal's use of motivational, supervisory, conflict management and communication strategies enhance teachers' productivity.

Teachers, as one of the major stakeholders in education, need to manage both students and knowledge, monitor students' progress and provide guidance services under the guidance and supervisory role of the principal (Onuma, 2016). Therefore, the provision of management support practices by school principals is essential for teachers' performance in building sufficiently motivated and effective teachers (ibid). Lemos, Muralidharan and Scur (2017) also established a relationship between management practices and school productivity while Price and Moolenaur (2015), reports that principals are greatly dependent on their teachers to reach school goals as teachers form the bridge from administration to classroom.

\section{Materials and Methods}

\subsection{Theoretical Framework}

More often, teachers are held responsible for the success or failure of educational organization because their productivity reflect the productivity of the system. Nakopdia (2001) emphasized that teachers count more important than any other factor which contributes to the quality of education at any level of our educational system. Teacher productivity is the ratio of output produced by the teachers, here the output refers to the quality and quantity of students produces by the teachers (Yusuf \& Adigun, 2010). Johnson and Birkland (2003), also defined teacher productivity as a measure of the quantity and quality of the outcome, to their inputs in any aspect of their activities as teachers such as test results, graduation rates, dropout rates, labour market outcome, school climate, teacher commitment and discipline. Looking at these definitions, the second definition by Johnson and Birkland is more appropriate for this study given that it looks at the output of teachers with respect to their input.

Teachers cannot give what they do not have. Their output is a determinant of their input which also gives room for proper evaluation. Owoeye (1999) in Getange (2016), asserted that variables of teachers' productivity such as effective teaching, lesson note preparation, effectiveuse of scheme of work, effective supervision, monitoring of students' work and disciplinary ability are virtues which teachers should uphold effectively in the school system. Getange (2016) explained that productivity on the part of the teachers is determined by their level of participation in the day to day running of the school, regularity in school, class attendance, and student's level of discipline and proper use of instructional materials to facilitate learning process.

In this regard, the teachers' performance could be measured through annual report of the activities in terms of performance in teaching, lesson preparation, lesson presentation, mastery of subject matter, competence, teachers' commitment to job and extra-curricular activities. Other areas of assessment include effective leadership, effective supervision, effective monitoring of students' work, motivation, class control and disciplinary ability of 
the teachers. All these variables listed above that are linked to the productivity of teachers can only be effective if the principal's management or administrative strategies are effective. Principals are internal evaluators of teachers, as such, can better influence the job of the teacher, provided they have a good strategy.

Strategy, according to Nichols (2012), is the means by which policy is implemented. Bush and Coleman (2000) opined that strategy is an overview of the organization which encompasses all its activities. Strategies used by principals within the context of this study are the various ways that principals use to implement policies in education effectively and efficiently for teachers to be productive. School improvement research has shown that leadership is important in producing good student outcomes (Harris, 2002). According to Millette (1988), principals as schools chief executives are charged with this taunting task of managing teachers among other school resources.

The quality of management makes the difference between the success and failure of a school. Ramsey (1999) contends that, in an organization like the school, students and staff tend to live up to the image of the head teacher; because no school is high performing without an effective and efficient head teacher; he is the gospel that his/her staff and pupils read, a model of behaviour and work attitude to be copied by all. It implies that the head teacher is expected to accept responsibility for whatever pupils and staffs do and lead both by word and action, creating a school climate that facilitates effective teaching and learning. To this end, no meaningful development could be achieved in the school system without the appropriate strategies to stirrup the commitment of teachers on part of the school principal as regards their productivity (Orodho, Waweru,\&Getange, 2014; Republic of Kenya,2013).

Motivational strategies and teachers' productivity was identified by Getange (2016) as related constructs that influence the quality of education; effective and efficient motivational strategies by the school principals ensure teachers' productivity in the school system. Principal's supervisory strategies in the study carried out by Okorie and Nwiyi (nd) enhances teacher's effectiveness in secondary schools. Other principal's strategies identified by researchers to influence teachers' productivity includes communication strategies (Nwosu, 2017), instructional and administrative strategies (Akiri, 2014), and appraisal, internal supervision and administrative strategies (Wakoli, 2014). Therefore, secondary school principals play a pivotal role in enhancing the productivity of teachers using one or more of the strategies listed above.

\subsection{Data Management and Hypothesis Testing}

A cross-sectional survey research design was used in this study. Likert scale survey questionnaire was used to collect data from teachers based on the four objectives of the study. The total population of teachers in Government Secondary (both secondary technical and general) Schools in Fako Divison is approximately 1421 (Regional Delegation of Secondary Education, South West Region, 2017). From the table of Krejcie and Morgan (1970), for a population of 1400, a sample of 302 and above is convenient for the study. With this justification, 350 teachers were selected for the study. All schools were represented in the study but only teachers with at least three years of teaching experience were selected for the study. This was to enable the researcher get valuable information for the study. Therefore, a multi-stage sampling technique was used to select the teachers from each school in the Division. Descriptive and inferential statistics were used to test the reliability of the assertions reported in the survey. Any respondent who scored 14 and above was under Highly Encouraged, Always, and Very Frequent depending on the variable under investigation. Any respondent who scored between 11 and 14 was classified under Encouraged, Sometimes, and Frequent. Any respondent who scored below 11 was categorized under Not Encouraged, Never and Not Frequent. All the responses for the dependent variable were scored and classified. Any respondent who scored 13 and above were categorized as high output, below this value was categorized as low output.

The hypotheses were verified using inferential analysis of the Chi-Square $\left(\chi^{2}\right)$ where

$$
\chi^{2}=\sum \frac{(O-E)^{2}}{E}
$$

Here, $\chi^{2}$ critical value $=3.841, \alpha=0.05$ level of significance, degree of freedom $=1$. The frequencies in brackets are the expected frequencies while those without brackets are the observed frequencies for all tables used in calculating chi square. The magnitude by which teachers' productivity is enhanced by motivation, conflict resolution, supervisory and communication strategies used by the principal is determined by comparing the contingency coefficient value (c.c) to the contingency maximum value (Cmax), shown in table 1 . 
Table 1. Magnitude of relationship

\begin{tabular}{lll}
\hline Range & Magnitude & Cmax \\
\hline $\mathbf{0 . 4 - 0 . 7 1}$ & High & 0.71 \\
$\mathbf{0 . 3 - 0 . 3 9}$ & Moderate & \\
$\mathbf{0 - 0 . 2 9}$ & Low & \\
\hline
\end{tabular}

\section{Results and Discussion}

\subsection{Gender of Teachers}

Both male and female teachers were represented in the sample, which was slightly dominated by female teachers (56\%) while male teachers constitute $44 \%$ of the participants. It was observed in the field that in most schools, the female population is greater than the male population of teachers. This indicated that more females are getting into the teaching profession than their male counterpart. Principals, being the central source of leadership influence are expected to look into gender issues of teachers to facilitate continuous school improvement. Therefore, the principal should put in strategies to know the insight of female teachers' problems and how to solve these problems to improve on their productivity.

\subsection{Teaching Longevity and Duty Position}

Most teachers (52.3\%) have taught in their institutions between 5 to 10 years which was suitable for the research since most of the teachers did not find it difficult to understand the questions and providing adequate responses. This was followed by those who have taught for 10 years who account for $27.4 \%$ and above and lastly those who have taught between 3 to 5 years $(20.3 \%)$ in the schools (see table 2). This also indicates that teachers transfer is not frequent, as such, has positive implication on students' performance. When teachers are stable, they can better understand the students in terms of their strength and weaknesses which may improve on students' performance.

Table 2. Longitivity in teaching

\begin{tabular}{lll}
\hline Number of Years Taught & Frequency & Percentage \\
\hline 3-5 years & 71 & 20.3 \\
5-10 years & 183 & 52.3 \\
10 years and above & 96 & 27.4 \\
Total & $\mathbf{3 5 0}$ & $\mathbf{1 0 0 . 0}$ \\
\hline
\end{tabular}

Source: Field Survey, 2017.

A very large proportion of the teachers (96.6\%) do not hold any post of responsibility while $3.4 \%$ hold post of responsibility (see table 3). The post of responsibilities included discipline master/mistress, head of department, vice principal and class master. While some of these teachers have held these positions for less than a year, others have held their positions for more than five years.

Table 3. Teachers with post of responsibility

\begin{tabular}{lll}
\hline Response & Frequency & Percentage \\
\hline Yes & 12 & 3.4 \\
No & 338 & 96.6 \\
Total & $\mathbf{3 5 0}$ & $\mathbf{1 0 0 . 0}$ \\
\hline
\end{tabular}

Source: Field Survey, 2017

About $41.7 \%$ of those who have held posts of responsibilities have held it for five years and above. Another 33.3\% have held it between 2 to 5 years while $25 \%$ have held it between 0 to 2 years. Teachers with post of responsibilities are more frequent in school than those without post of responsibility. By implication, they are liable to have frequent contact with the principal (see table 4). 
Table 4. Longitivity in post of responsibility

\begin{tabular}{lll}
\hline Duration & Frequency & Percentage \\
\hline 5 years and above & 5 & 41.7 \\
$\mathbf{2 - 5}$ years & 4 & 33.3 \\
$\mathbf{0 - 2}$ years & 3 & 25 \\
Total & $\mathbf{1 2}$ & $\mathbf{1 0 0 . 0}$ \\
\hline
\end{tabular}

Source: Field Survey, 2017.

Table 5 shows that most of the teachers $(54.9 \%)$ indicated that they do not have monthly meeting with their principals. About $40.6 \%$ of the teachers indicated that they have meeting with the principal one's a month while $3.5 \%$ indicated that they have meeting with the principal two times a month.

Table 5. Meetings with principals

\begin{tabular}{lll}
\hline Responses & Frequency & Percentage \\
\hline Zero time a month & 196 & 54.9 \\
One time a month & 146 & 40.6 \\
Two times a month & 12 & 3.5 \\
Three times and above & 0 & 0 \\
Total & $\mathbf{3 5 0}$ & $\mathbf{1 0 0 . 0}$ \\
\hline
\end{tabular}

\subsection{Motivational Strategies and Teachers' Productivity}

About $67.7 \%$ of the teachers said that the principal sometimes motivate them. Another $16.9 \%$ indicated that the principal always uses motivation to encourage them to work and appreciate their effort while $15.4 \%$ were of the opinion that the principal do not motivate them as shown in table 6. Majority of the teachers have positive opinion on principals' motivation. Motivation is an integral part of teachers' productivity and teachers' look up to the principal who is the head of the school for their needs. Motivational strategies have always been regarded as the internalized drive that is more dominant in an individual at a given moment which is integral and essential part of the secondary school administration. To this end, no meaningful development could be achieve in the school system without the appropriate strategies to stirrup the commitment of teachers on the part of the school principal as regards their productivity (Orodho, Waweru, \&Getange, 2014; Republic of Kenya, 2013). According to Getange (2016), the achievement of quality education rests squarely on the shoulders of teachers who need appropriate motivation to produce the desired educational productivity. Given the fact that education is one of the important factors that help in bringing about rapid social and economic development in any given nation, the role of principals and teachers cannot be downplayed. However, concerted efforts are always made through effective and efficient motivational strategies by the school principals to ensure teachers' productivity in the school system.

Table 6. Perception on motivation strategies used by principals

\begin{tabular}{lll}
\hline Use of Motivation Strategies & Frequency & Percentage \\
\hline Sometimes & 237 & 67.7 \\
Always & 59 & 16.9 \\
Never & 54 & 15.4 \\
Total & $\mathbf{3 5 0}$ & $\mathbf{1 0 0 . 0}$ \\
\hline
\end{tabular}

Source: Field Survey, 2017.

The principal in performing these roles and functions and considering the roles that teachers play in attaining the goals and objectives of secondary education, should be able to bring out the best in teachers; that internal drive that encourages them to do what they are suppose to do by putting in positive motivational strategies. These strategies may be monetary, conducive working environment, positive school culture and climate, communication, delegation, praise amongst others depending on the situation. Sometimes a principal may use a particular strategy which may be good but does not meet up the need of the teacher. This becomes a de-motivator to the teacher(s) concern. Therefore, the principal has a responsibility to benchmark various ways in which he can motivate teachers which may be through positive interaction with teachers. Akerele (2007) and Analou (2000) report that, in order to maintain morale, and find ways to make each teacher more effective, the 
principal need to gather input from his staff on a regular basis. He should not necessarily know the detailed in and out of every teacher's job, but he can learn, help and guide his teacher to more efficient work habits by listening to their input and putting their ideas to good use. Therefore, principals can encourage effective productivity of their teachers by identifying their needs and trying to satisfy or meeting them through appropriate, relevant and adequate motivational strategies (Maicibi, 2003; Orodho, 2013; Ouma, 2007). Nevertheless, a combination of financial and non-financial incentives help together in bringing motivation and zeal to work in a concern that really enhance the productivity of teachers in the school system (Mumanyire, 2005). In organizational psychology, it is frequently expressed that job productivity is a function of ability and motivation on the part of the leader (Dugu, 2000; Fechlin \& Olivia, 1993).

Table 7 shows that out of 263 teachers with low output in productivity, 218 indicated that principals sometimes use motivational strategies to improve on their productivity, 31 indicated that the principal always motivate them to work while 14 indicated that they are never motivated by the principal. Out of 87 teachers with high output in productivity, 19 were of the opinion that principals sometimes motivate them, 28 indicated always while 40 said that they were never praised by the principal. The $\chi^{2}$ calculated value is 122.1 . Since $\chi^{2}$ calculated value (122.1) is greater than $\chi^{2}$ critical value (3.841), we reject the null hypothesis. Inference leads us to conclude that teachers' productivity is enhanced by motivational strategy used by principals. The c.c is 0.51 , while $C_{\max }$ is 0.71 . Since 0.51 lies within 0.4 and 0.71 , the magnitude is high. That is, teachers' productivity is highly enhanced by motivation from the principal.

Table 7. Teachers' productivity and motivational strategies

\begin{tabular}{llll}
\hline Motivational Strategy & $\begin{array}{l}\text { Teachers' Productivity } \\
\text { Low output }\end{array}$ & High output & Total \\
\hline Sometimes & $218(178)$ & $19(59)$ & 237 \\
Always & $31(44.3)$ & $28(14.7)$ & 59 \\
Never & $14(40.6)$ & $40(13.4)$ & 54 \\
Total & $\mathbf{2 6 3}$ & $\mathbf{8 7}$ & $\mathbf{3 5 0}$ \\
\hline
\end{tabular}

Source: Field Survey, 2017.

This study is in line with the findings of Acheck (2015) on motivational strategies used by principals in the management of secondary schools in Fako Division, South West Region of Cameroon. Results established that, use of motivational strategies by principals which range from exhibiting positive leadership characteristics, being empathic, supportive and compassionate to the needs and desires of teachers and leading through transformational leadership practices affect teachers' productivity. Motivational strategies used by principals among others have a very significant importance in the teaching-learning process. In order words, there is a positive correlation between motivation and the effectiveness of the teaching-learning process. In ascertaining the factors that influence motivation among secondary school teachers in the area under study, school principals acknowledged that extrinsic and intrinsic factors influence motivation in the Division with the extrinsic factor of the "general state of the nation's economy" being the first influence. The study in general shows teachers believe very much in the use of financial or economy rewards in schools as motivational strategies.

Getange (2016) also concluded thatprincipals' motivational strategies (condition of service, effective communication, interpersonal relationship, end of year award and commendation at meeting) have positive and significant influence on teachers' productivity. It further established that condition of service, interpersonal relationship, end of year award and commendation at meeting exhibited by the school principals in the study area had a greater influence on teachers' productivity in terms of use of instructional materials.

\subsection{Supervisory Strategies and Teachers' Productivity}

About $46.6 \%$ of the teachers indicated that they were not encouraged by the principal's supervisory strategy, $39.4 \%$ were encouraged while $14 \%$ were highly encouraged. This implies that, $(53.4 \%)$ were encouraged by principals' supervisory strategy, see table 8 . For the expected results of secondary education to be attained, principals' supervisory strategy must have a positive impact on teachers' performance or productivity. Efanga (2001, pp.156-157) explained that, Adequate strategic supervision has the capacity of impacting much on the effectiveness of the teachers. For instance, if an administrator sets up his strategies to supervise teachers' use of time, check how materials and supplies are utilized, coordinate student bodies to assist the teachers, make sure that teachers' notes of lessons and other records are up-to-date, there is a probability that tearchers will be effective in the performance of their duties. Though within the context of study there are pedagogic inspectors in 
all the regional delegations of secondary education in Cameroon in charge of supervising teachers, principals as internal evaluators come in contact with teachers on regular bases and have a greater role to play in impacting teachers' productivity. They can better understand teachers' strength and weaknesses and employ supervisory strategies that can improve on their output.

Table 8. Perception on supervisory strategy used by principals

\begin{tabular}{lll}
\hline Supervisory Strategy & Frequency & Percentage \\
\hline Not Encouraged & 163 & 46.6 \\
Encouraged & 103 & 39.4 \\
Highly Encouraged & 84 & 14.0 \\
Total & $\mathbf{3 5 0}$ & $\mathbf{1 0 0 . 0}$ \\
\hline
\end{tabular}

Source: Field Survey, 2017.

When the principal adopts good supervisory strategy, the teacher's will be effective in performing the prescribed duties which invariably would lead to the achievement of the goals of secondary education (Nwiyi and Uriah, 2007). Table 9 shows that, out of 263 teachers classified under low output, 151 were not encouraged with the supervisory strategy used by the principal, 78 were encouraged while 34 were highly encouraged. Out of 87 teachers classified under high output, 12 were not encouraged, 25 were encouraged and 50 were highly encouraged with the principal supervisory strategy. The $\chi^{2}$ calculated value is 80.75 . Since $\chi^{2}$ calculated value (80.75) is greater than $\chi^{2}$ critical value (3.841), we reject the null hypothesis following the decision rule. Inference leads us to conclude that teachers' productivity is enhanced by principals' supervisory strategy. The c.c is 0.43 and $\mathrm{C}_{\max }$ is 0.71 . Since 0.43 lies within 0.4 and 0.71 , the magnitude is high. This implies teachers' productivity is highly enhanced by supervisory strategy used by the principal.

Table 9. Teachers' productivity and supervisory strategy

\begin{tabular}{llll}
\hline Supervisory Strategy & $\begin{array}{l}\text { Teachers' Productivity } \\
\text { Low output }\end{array}$ & High output & Total \\
\hline Not Encouraged & $151(122.5)$ & $12(40.5)$ & 163 \\
Encouraged & $78(77.4)$ & $25(25.6)$ & 103 \\
Highly Encouraged & $34(63.12)$ & $50(20.88)$ & 84 \\
Total & $\mathbf{2 6 3}$ & $\mathbf{8 7}$ & $\mathbf{3 5 0}$ \\
\hline
\end{tabular}

Source: Field Survey, 2017.

This finding corroborates with the findings from a research study carried out by Okorie and Nwiyi (nd) on principals' supervisory strategy and teachers' effectiveness which revealed that, delegation of supervisory function, effective record keeping and teacher monthly assessment supervisory strategies improved on teachers' effectiveness in secondary schools. While taking into consideration the goals of the organization, the goals and objectives of the individual teacher must be given a serious taught when strategizing; a happy teacher is a productive teacher.

\subsection{Conflict Management Strategies and Teachers' Productivity}

About $72.9 \%$ of the teachers were classified to have said that they were not encouraged with the method in which the principal resolve conflict amongst teachers. 19.7 were encouraged with the principal's conflict resolution strategy while $7.7 \%$ were highly encouraged with the manner in which principals resolve conflict amongst teachers. As noted in table 10, given that a majority of the teachers $(72.9 \%)$ were not encouraged by the principals' conflict management strategy implies that the principals lack appropriate conflict resolution strategy to improve on teachers' collaboration and productivity. Effective collaboration amongst teachers and staff is relevant for teacher effectiveness and job satisfaction because they may need help in one way or the other from their colleagues for effective implementation of their duties. Akiri (2014) reported that as the principal occupies a very significant position in the school system, for him to be effective, he needs amongst others: drive, energy, vision, personality and management in conflict resolution techniques. However, work group usually have a tendency to compete for limited resources, power and status, to the extent of disrupting the cooperative efforts. Teachers are individuals in the educational organization, having varied backgrounds, culture, goals and objectives to attain. As such, there are bound to be conflict of ideas, personality, likes and dislikes. However, for the goals and objectives of education to be attained, they must collaborate. Therefore, the principal as the head of 
secondary education need to employ effective conflict management strategies to enable teachers collaborate effectively to improve on their productivity.

Table 10. Perception on conflict management strategy used by principals

\begin{tabular}{lll}
\hline Conflict Management Strategy & Frequency & Percentage \\
\hline Not Encouraged & 255 & 72.9 \\
Encouraged & 69 & 19.4 \\
Highly Encouraged & 26 & 7.7 \\
Total & $\mathbf{3 5 0}$ & $\mathbf{1 0 0 . 0}$ \\
\hline
\end{tabular}

Source: Field Survey, 2017.

As noted in table 7, the Chi-Square $\left(\chi^{2}\right)$ calculated value is 204 , and $\chi^{2}$ critical value is 3.841 . Since $\chi^{2}$ calculated value (205) is greater than $\chi^{2}$ critical value (3.841), we reject the null hypothesis following the decision rule. Inference leads us to conclude that teachers' productivity is enhanced by principals 'conflict management strategy. The c.c is 0.61 and Cmax is 0.71 . Since 0.61 lies within 0.4 and 0.71 , the magnitude is high. This implies teachers' productivity is highly enhanced by conflict management strategy used by the principal.

Table 11. Conflict management strategy and teachers' productivity

\begin{tabular}{llll}
\hline Conflict management strategy & \multicolumn{2}{l}{ Teachers' Productivity } & \\
& Low output & High output & Total \\
\hline Not Encouraged & $243(191.6)$ & $12(63.4)$ & 255 \\
Encouraged & $14(51.8)$ & $55(17.2)$ & 69 \\
Highly Encouraged & $6(19.5)$ & $20(6.5)$ & 26 \\
Total & $\mathbf{2 6 3}$ & $\mathbf{8 7}$ & $\mathbf{3 5 0}$ \\
\hline
\end{tabular}

Source: Field Survey, 2017

This study corroborates the findings of Aniefiok, Uduak and Williams (2017) who concluded that Principals "conflict resolution strategies in conjunction to other motivational techniques are the most effective solution to the problem of teachers" job effectiveness in public secondary schools in Akwalbom State, Nigeria. They further noted that, cause identification strategy and integration strategy related positively to teachers' job effectiveness in terms of classroom teaching, maintenance of classroom discipline and supervision of students' academic activities.

\subsection{Communication Strategies and Teachers' Productivity}

About $50.3 \%$ of the teachers indicated that communication with the principal is not frequent. Another $29.7 \%$ were of the opinion that communication is frequent while $20.0 \%$ indicated that communication with the principal is very frequent. As shown in table 12 , less than half of the participants $(49.7 \%)$ have frequent communication with their principals. Communication is a very sensitive aspect of organizational management and it ineffectiveness may have adverse effects on the productivity of teachers. For example without effective and frequent communication, it will be difficult to tell whether teachers are effective or not or whether they have difficulties or not; information is strength. Nwosu (2017) explained that, communication has been found to be a central factor for effective job performance. Investigations reveal that principals' ability to communicate, increased teachers' morale, reduced misunderstanding and interpersonal conflict among staff and consequently enhanced teacher effectiveness (ibid). Therefore, effective communication will have a positive impact on the productivity of teachers; it has an influence on the perception and opinions about persons, positive school climate, effective implementation of goals and objectives, amongst others. As a managerial tool, communication is frequently expected to share information with members, to coordinate activities, to reduce unnecessary managerial burdens and rules, and ultimately to improve organizational performance (Nwosu, 2017). 
Table 12. Perception on principal's communication strategy used by principals

\begin{tabular}{lll}
\hline Communication Strategy & Frequency & Percentage \\
\hline Not Frequent & 176 & 50.3 \\
Frequent & 104 & 29.7 \\
Very Frequent & 70 & 20.0 \\
Total & $\mathbf{3 5 0}$ & $\mathbf{1 0 0 . 0}$ \\
\hline
\end{tabular}

Source: Field Survey, 2017.

As an effective communication strategy, teachers should be involved in decision making in matters that affects them. This will assist the principal in effective decision making and effective implementation and consequently high output. Friedman (1991) supported this claim in his own study, that insufficient decision - making participation influenced effectiveness of teachers. These findings were equally supported by the works of Sairos and Sairos (1992), Hipps and Halpin (1992) and Dinhan (1992). Other researchers on participation of teachers in decision - making in schools revealed a positive correlation between participation in decision - making and teachers' productivity. It is logical that by involving teachers in decisions that affect them and by increasing their autonomy and control over their work lives through appropriate communication, employees would become more motivated, more committed to the organization, more productive and more satisfied with their job. Ekara (1996) also found out that teachers who had opportunity to participate always and actively in decision - making processes of the school were more enthusiastic about their system than those who had limited opportunity to participate.

Out of 176 teachers who do not have frequent communication with their principals, 146 have a low output while 30 have a high output. Out of 104 teachers who frequently communicated with the principals, 95 have low output while 9 have high output. Out of 70 teachers who communicate frequently with their principals, 32 have a low output as shown in table 13. The Chi-Square $\left(\chi^{2}\right)$ calculated value is 52.9 , while $\chi^{2}$ critical value is 3.841 . Since $\chi^{2}$ calculated value (52.9) is greater than $\chi^{2}$ critical value (3.841), we reject the null hypothesis following the decision rule. Inference leads us to conclude that teachers' productivity is enhanced by the principals' communication strategy. The c.c is 0.36 and $\mathrm{C}_{\max }$ is 0.71 . Since 0.36 lies within 0.35 and 0.4 , the magnitude is moderate. This implies teachers' productivity is moderately enhanced by communication strategy used by the principal. Results from the hypotheses in table 13 showed that communication strategies used by the principals, to some extent affects teachers' productivity.

Table 13. Communication strategy and teachers' productivity

\begin{tabular}{llll}
\hline Communication Strategy & \multicolumn{2}{l}{ Teachers' Productivity } & Total \\
\cline { 2 - 3 } Not Encouraged & Low output & High output & 176 \\
Encouraged & $146(132.3)$ & $30(43.75)$ & 104 \\
Highly Encouraged & $95(78.1)$ & $9(25.9)$ & 70 \\
Total & $32(52.6)$ & $38(17.4)$ & $\mathbf{3 5 0}$ \\
\hline
\end{tabular}

Source: Field Survey, 2017.

\section{Conclusion}

Results from findings showed that principals' communication, conflict management, supervisory and motivation strategies influence the productivity of teachers in Government Secondary Schools in Fako Division in the South West Region of Cameroon. Of all these strategies, conflict management influences the productivity of teachers more than the other strategies with a contingency coefficient (c.c.) value of 0.61 , followed by motivational strategies $($ c.c. $=0.51)$, supervisory strategies $($ c.c. $=0.43$ ) and lastly communication strategies $($ c.c. $=0.36)$. Findings concluded that, principals' strategies have a direct relationship with teachers' productivity. Therefore, there is a correlation between principals' leadership/management strategies, teachers' productivity and school effectiveness. In addition, effective collaboration amongst teachers is necessary for teachers' effectiveness. On a general note, principals are recommended to put in strategies that will enhance effective communication, conflict management, motivation and supervision to improve on the productivity of teachers. The specific recommendations include the following:

1) Given that motivation is an integral part of teachers' job performance, principals should employ motivational strategies that will meet the needs of teacher to improve on their performance. 
2) Supervision of teachers should be based on improvement and not sanction. Principals should clearly state their objectives of supervision and communicate it to teachers to enable the principal gather relevant information during the process that may assist in improving the productivity of teachers.

3) Principals should establish and encourage culture and climate that encourages collaboration and reduce conflict amongst teachers.

4) Communication is relevant for effective implementation of goals and objectives. As such, principals should put in effective communication procedures for teachers to have relevant and reliable information on time.

\section{References}

Achech, T. A. (2015). Motivational Strategies used by Principals in the Management of Schools. The case of some selected Secondary Schools in Fako Division in the South West Region of Cameroon. Unpublished Masters' Thesis, Department of Education, UUniversity of Jyvaskyla.

Akerele, S. A. (2007). Principals leadership style and teachers' job performance in Lagos State Public Secondary Schools. Unpublished M.Ed Thesis, University of Ado- Ekiti, Nigeria, pp. 110-124.

Akiri, A. A. (2014). Assessment of Instructional and Administrative Strategies applied by principals to improve Academic Performance. International Journal of Educational Administration and Policy Studies, 6(7), 112-114.

Analoui, F. (2000). What motivates senior managers? The case of Romania. Journal of Managerial Psychology, 15(4), 324-340. https://doi.org/10.1108/02683940010330984

Aniefiok, O. E., Uduak, R. B., \& Williams, R. (2017). Principals' Conflict Resolution Strategies and Teachers' Job Effectiveness in Public Secondary Schools in Akwa Ibom State, Nigeria. Journal of Education and Social Research, 7(2), 153-158. https://doi.org/10.5901/jesr.2017.v7n2p153

Bush, T., \& Coleman, M. (2000). Leadership and strategic management in education. London: Paul Chapman publishing Ltd.

Cameroon. (1998). Law No 98/004 of 14 April 1998 to lay down Guidelines for Education in Cameroon. Yaounde: Ministry of National Education.

Dungu, L. (2000). Accommodation and job performance of primary school teachers in Rakai district. Unpublished Masters Dissertation Makerere University, Kampala, Uganda.

Effanga, S. I. (2001). Teachers and effective classroom management. In D. N. Urnuoren \& C. M. Ogbodo (Eds.), $A$ hand book on teaching profession in Nigeria (pp. 47-60). Uyo: Guidepost publishers.

Fagbamiye, E. O. (2004). Providing cost-effective education in Nigeria. In E. O. Famigbaye, J. B. Babalola, M. Fabunmi, \& A. Ayeni (Eds.), Management of primary and secondary education in Nigeria (pp.121-137). Ibadan: Codat Publications Limited.

Getange, K. N. (2016). Motivational Strategies and Teachers' Productivity: Lessons of Experience form Public Secondary Schoold in Kisii County, Kenya. Journal of Research and Methods in Education, 6(4), 33-38.

Harris, A. (2002). Effective Leadership in Schools Facing Challenging Contexts. School Leadership and Management, 22(1), 15-26. https://doi.org/10.1080/13632430220143024a

Johnson, S. M., \& Birkeland, S. (2003). Pursuing a 'Sense of Success': New Teachers Explain Their Career Decisions. American Educational Research Journal, 40(3), 581-617. https://doi.org/10.3102/00028312040003581

Krejcie, R. V., \& Morgan, D. W. (1970). Determining Sample Size for Research Activities. Educational and Psychological Measurement, 30, 608. https://doi.org/10.1177/001316447003000308

Lemos, R., Muralidharan, K., \& Scur, D. (2017). Personnel Management and School Productivity: Evidence from India. Empirical Management Conference: World Bank.

Maicibi, N. A. (2003). Pertinent issues in employees' management: human resource and educational management. Kampala. Net Media Monitor Publishers.

Millette, A. (1988). Tes/Kelle Lectures on Educational Leadership in the Millennium "Professionals, Pedagogy and Leadership". A lecture given on 3 June 1988.

Mutua, K. K. (2014). Household Factors Influencing Students Dropout in Public Secondary Schools in Kitui Central District, Kenya. Unpublished Masters Thesis.

Nichols, F. (2012). Improving the Performance of People, Process and Organizations. Distance Consultancy. 
Nwiyi, G. U., \& Uriah, O. A. (2007). Teacher empowerment and commitment to duty in River State. Journal of Pedagogy and Educational Development, 12(1), 84-89.

Nwosu, J. (2017). Principals' Communication Strategies and Teachers' Job Performance in Public Secondary Schools in Ikenne Local Government Area of Ogun State. International Journal of Education, Learning and Development, 5(1), 1-12.

Okorie, F. S., \& Nwiyi, G. U. (n.d.). The Principals Supervisory Strategies and Teachers' Effectiveness in Secondary Schools in Akwa Ibom School. Academic Discourse: An international Journal.

Onuma, N. (2016). Principals' Management Support Practices for Enhancing Teachers' Performance in Secondary School in Nigeria. International Journal of Education, Learning and Development, 4(3), 26-36.

Orodho, A. J., Waweru, P. N., \& Getange, K. N. (2014). Progress towards attainment of Education For All (EFA) among nomadic pastoralists: How do we dismantle the gender Differential jinx in Mandera County, Kenya?. International Organization of Scientific Research (IOSR) Journal of Humanities and Social Sciences (IOSR-JHSS), 19(2), 106-117. https://doi.org/10.9790/0837-1922106117

Orodho, J. A. (2013). Progress towards attainment of Education for All (EFA) among nomadic pastoralists: Do home-based variables make a difference in Kenya?. Research on Humanities and Social Sciences Pages, 54-67.

Owoeye, N. O. (1999). The Influence of job satisfaction on job performance of staff in the broadcasting service of Ekiti State and Ondo State Radio Corporation (pp. 65-73). Unpublished M.Ed Thesis of the Faculty of Education Ondo State University, Ado Ekiti.

Getange, K. N. (2016). Motivational Strategies and Teachers' Productivity: Lessons of Experience form Public Secondary Schoold in Kisii County, Kenya. Journal of Research and Methods in Education, 6(4), 33-38.

Price, E. P., \& Moolenaur, N. M. (2015). Principal-Teacher Relationship: Foregrounding the International Importance of Principals' Social Relationships for School Learning Climates. Journal of Educational Administration, 53(1). https://doi.org/10.1108/JEA-11-2014-0134

Ramsey, R. D. (1999). Lead, Follow, or Get Out of the Way: How to be a more effective leader in today's schools. California: Corwin Press Inc.

Republic of Kenya. (2013). The Basic Education Act 2013; No. 14 of 2013. Government Printers, Nairobi.

Yusuf, M. A., \& Adigun, J. T. (2010). The Influence of School Climate Change on Teachers' Productivity And Students' Achievement. Journal of Research in National Development, 8(2).

\section{Copyrights}

Copyright for this article is retained by the author, with first publication rights granted to the journal.

This is an open-access article distributed under the terms and conditions of the Creative Commons Attribution license (http://creativecommons.org/licenses/by/4.0/). 